Revista de Ciencias Sociales - Número 67 (2015) - Páginas 101-126

El constitucionalismo político

\title{
EL CONSTITUCIONALISMO POLÍTICO
}

\section{THE POLITICAL CONSTITUTIONALISM}

\author{
HUGO TÓRTORA ARAVENA* \\ Universidad Andrés Bello (Chile) \\ hugotortora@gmail.com
}

\begin{abstract}
Resumen
La expresión constitucionalismo es usada en diferentes sentidos, tanto desde la Teoría del Derecho, como de la Teoría Política y el Derecho Constitucional. Este trabajo busca trazar las diferencias entre el llamado constitucionalismo jurídico, principalmente dirigido al rol de la constitución dentro del ordenamiento jurídico, y el constitucionalismo político, con énfasis en el control y la limitación del poder político. Se entenderá que no existe por lo tanto, una única definición correcta del término, sino más bien, se trata de diversos usos válidos respecto de la misma palabra.
\end{abstract}

\section{Palabras claves}

Constitucionalismo, Constitución, Poder político, Neoconstitucionalismo, Derechos Fundamentales.

* Abogado, Licenciado en Ciencias Jurídicas por la Universidad de Valparaíso. Magíster en Derecho Constitucional por la Universidad de Talca y doctorando en Derecho por la Universidad de Valparaíso. Profesor de Derecho Público de la Universidad Andrés Bello. Contacto: Calle Quillota 980, Viña del Mar. Artículo recibido el 9 de octubre de 2015 y aceptado el 30 de noviembre de 2015.

Revista de Ciencias Sociales - Número 67 (2015) - Universidad de Valparáíso - ISSN 0716-7725-Valparáiso, Chile

101 


\section{Abstract}

Constitutionalism expression is used in different ways, both Legal Theory, as Political Theory and Constitutional Law. This paper seeks to trace the differences between the so-called legal constitutionalism, mainly directed to the role of the constitution in the legal system, and political constitutionalism, with emphasis on the control and limitation of political power. It is understood that there is therefore a single correct definition of the term, but rather, is much valid regarding the same word uses.

\section{Keywords}

Constitutionalism, Constitution, Political power, Neoconstitutionalism, Human rights.

\section{Introducción}

La historia del Constitucionalismo es una narración acerca de la relación que se ha dado en el tiempo entre los derechos fundamentales y el poder. Cada estadio del Constitucionalismo ha pretendido la mejor protección de aquellos derechos, a través de herramientas o mecanismos que, habitualmente, terminan plasmados en las Constituciones o, al menos, en las prácticas constitucionales. Por lo mismo, ni el Constitucionalismo ni los derechos fundamentales son fenómenos estáticos que se hayan asentado en alguna época determinada y que se hayan quedado inalterados hasta nuestros días.

Un interesante punto de inicio sobre esta temática es la expresión de Constant quien, luego de haber defendido el quiebre con el antiguo régimen francés, se levantó en contra de los excesos cometidos por el Régimen del Terror y por Napoleón Bonaparte, sosteniendo: "yo he defendido durante cuarenta años el mismo principio: la libertad en todo: en religión, en filosofía, en industria, en política; y por libertad entiendo el triunfo de la individualidad, tanto sobre la autoridad que quería gobernar desde el despotismo, como sobre las masas que reclaman el derecho de someter la minoría a la mayoría". Más allá del liberalismo moderado del autor,

1. CONSTANT DE REBEQUE, Henri-Benjamin: Mélanges de littérature et de politique. Pichon et Didier, Libraires-Éditeurs, París, 1829. Pág. VI. Traducción mía.

Facultad de Derecho y Ciencias Sociales - Universidad de Valparaíso - Chile 
lo que hay detrás de sus palabras es la convicción que la libertad puede tener diferentes enemigos que se alzan como amenaza en contra de los derechos de las personas. Y es ahí donde el constitucionalismo comienza a operar, a partir de construcciones doctrinarias y movimientos sociales que logran construir modelos o arquetipos que se presentan como alternativas de solución al conflicto entre derechos y poder.

\section{Usos de la expresión constitucionalismo}

Uno de los problemas que acarrea usar el vocablo "constitucionalismo" es que se trata de una palabra polisémica y que se emplea en diversos contextos. Atienza advierte que es una expresión ambigua ${ }^{2}$, mientras que Ferrajoli sostiene que sobre este término existen "diversas concepciones" aspectos, equívoca y engañosa ${ }^{4}$.

Precisamente Ferrajoli trabaja con una distinción que será vital para este trabajo, cuando diferencia el constitucionalismo político del jurídico. El constitucionalismo político lo entiende como la práctica y la concepción de los poderes públicos dirigida a su limitación, en garantía de determinados ámbitos de libertad; mientras que el Constitucionalismo jurídico se circunscribe a la idea de subordinación de los poderes públicos, incluido el legislativo, a las normas superiores, específicamente a las normas constitucionales que establecen derechos fundamentales. Más tarde, propondrá que dentro de la experiencia jurídica, existe tanto un constitucionalismo rígido presente en las actuales democracias constitucionales, caracterizado por la existencia positiva de una lex superior a la legislación ordinaria (que él denomina

2. ATIENZA, Manuel: "Constitucionalismo, Globalización y Derecho”. En: Carbonell, Miguel y García Jaramillo, Leonardo (edic.): El canon neoconstitucional. Trotta, Madrid, 2010. Pág. 264.

3. FERRAJOLI, Luigi: "Constitucionalismo principialista y constitucionalismo garantista”. En: Ferrajoli, Luigi et al.: Un debate sobre el constitucionalismo. Monográfico Revista Doxa, N³4, Marcial Pons, Madrid, 2012. Pág. 16.

4. Ídem. Pág. 18.

Revista de Ciencias Sociales - Número 67 (2015) - Universidad de Valparáíso - ISSN 0716-7725-Valparáiso, Chile 
constitucionalismo jurídico o Estado constitucional de derecho), como también un modelo jurídico donde, o bien no existe constitución, o bien se trata de una constitución flexible (Estado legal o Estado flexible). Lo importante de esta última distinción es que solo al constitucionalismo jurídico o Estado constitucional de derecho, lo llamará "constitucionalismo"

Esta última concepción es criticada certeramente por Comanducci, entre otros motivos, por cuanto si esta palabra se usa solo para aludir al constitucionalismo jurídico, entonces habría que buscar otra manera de aludir al constitucionalismo político ${ }^{6}$. No obstante esto, la distinción primaria de Ferrajoli es importante, ya que evidencia los dos usos que se le da a esta expresión, los cuales si bien son reconocibles, no funcionan aisladamente, sino que existe interdependencia entre ellos, tal como se explicará más adelante. Estos son: constitucionalismo en un sentido jurídico y constitucionalismo en un sentido político, mientras que en este último se distinguirá a su vez el constitucionalismo político como formas históricas de organización, como construcción teórica, como movimiento, y como modelo.

Al término de este repaso de los diferentes usos que se le da a la expresión constitucionalismo, se explicitará cuál será el que se le dará en este trabajo, lo que en ningún caso querrá decir que es el concepto correcto del término, por cuanto esto va a depender del contexto en el que se emplee esta palabra.

\section{Constitucionalismo en sentido jurídico}

Entendemos por constitucionalismo en sentido jurídico, los usos que se le da a este término desde la perspectiva de la Teoría del Derecho, en especial, se refiere al rol que ocupa la constitución dentro de un ordenamiento jurídico, y los mecanismos que existen para hacerla efectiva.

5. Ídem. Pág. 15.

6. COMANDUCCI, Paolo: “'Constitucionalismo’: Problemas de definición y tipología”. En: Ferrajoli, ob. cit. Págs. 96-97.

Facultad de Derecho y Ciencias Sociales - Universidad de Valparaíso - Chile

104 
El primero de estos usos jurídicos es lo que Nino denomina “constitucionalismo en sentido mínimo”, en oposición al "constitucionalismo en sentido pleno" y se refiere a la necesidad que todo Estado cuente con una Constitución, vale decir, con una norma superior que restrinja la actividad legislativa normal. En este sentido, cada vez que un ordenamiento cuente con una constitución se cumple con las condiciones del constitucionalismo en sentido mínimo. De esta manera, agrega el autor, se puede afirmar que en la Unión Soviética de Stalin, o en la Sudáfrica del apartheid, o bajo la dictadura de Pinochet, había constitucionalismo ${ }^{7}$. Este sentido es escasamente reconocido en la ciencia jurídica, salvo cuando es usado por algunos trabajos principalmente de Derecho Comparado, tanto en un sentido espacial o sincrónico, como histórico o diacrónico ${ }^{8}$, de modo trivial ${ }^{9}$.

Entre los dos usos que explica el autor argentino, se encuentra uno intermedio y es aquel que entiende por constitucionalismo el ordenamiento jurídico que cuenta con una constitución que limita a los órganos del Estado, pero con el objetivo de evitar el despotismo.

7. NINO, Carlos Santiago: Fundamentos de derecho constitucional. Análisis filosófico, jurídico y politológico de la práctica constitucional. Astrea, Buenos Aires, $2^{\mathrm{a}}$ reimpr., 2002. Págs. 2-3.

8. VERGOTTINI, Giuseppe De: Derecho constitucional comparado. Universidad Nacional Autónoma de México, Segretariato Europeo per le Pubblicazioni Scientifiche, México D.F., $1^{\text {a }}$ ed., 2004. (Trad. Claudia Herrera). Pág. 50.

9. En el primero de los sentidos: BREWER-CARÍAS, Allan: "El constitucionalismo Latinoamericano y la Constitución para el Siglo XXI”. En: Discurso de Orden con motivo de la instalación de las V Jornadas Venezolanas de Derecho Tributario, Asociación Venezolana de Derecho Tributario, Caracas, 25 de Octubre de 2000. Disponible en: http://www.allanbrewercarias.com/Content/449725d9-flcb-474b8ab2-41 efb849fea2/Content/I.1.801.pdf (revisado el día 26 de julio de 2015); CARPIZO, Jorge: "Tendencias actuales del constitucionalismo latinoamericano". En: Revista Derecho del Estado, Universidad Externado de Colombia, Bogotá, $\mathrm{N}^{\circ} 23$, diciembre de 2009. Págs. 7 y ss.; WEILER, J.H.H. y WIND, Marlene (edic.): European constitutionalism beyond the state. Cambridge University Press, Cambridge, 2003. En el segundo, MCILWAIN, Charles Howard: Constitucionalismo antiguo y moderno. Centro de Estudios Constitucionales, Madrid, 1991. (Trad. Juan J. Solozábal Echavarría).

Revista de Ciencias Sociales - Número 67 (2015) - Universidad de Valparáíso - ISSN 0716-7725-Valparáiso, Chile 
Este Constitucionalismo es denominado por Troper "constitucionalismo lato sensu" ${ }^{\prime \prime}$, y no podría ser aplicado a los ejemplos concretos que daba Nino anteriormente, ya que no todo sistema que cuente con Constitución es constitucionalista ${ }^{11}$. Con el constitucionalismo lato sensu se comprueba que la distinción entre constitucionalismo jurídico y político es tenue, ya que la idea de un complejo normativo que busque poner frenos al poder tiene claramente una finalidad política que se expresa jurídicamente en los términos explicados.

Otro uso corresponde al aludido "constitucionalismo en sentido pleno" de Nino ${ }^{12}$, y que Troper llama "constitucionalismo stricto sensu"13. En este caso, el límite al poder posee un contenido específico, y corresponde a ciertos principios que buscan garantizar las libertades o derechos de las personas ${ }^{14}$. Comanducci explica que mientras el anterior constitucionalismo (que él llama "en sentido amplio") pretende la creación de una Constitución que limite el poder y prevenga el despotismo, éste busca un específico tipo de Constitución que cumpla dicho fin, a través de la defensa de los derechos fundamentales frente al poder estatal ${ }^{15}$. El constitucionalismo en sentido pleno o en sentido estricto puede ser entendido como una manifestación jurídica del

10. TROPER, Michel: Por una teoría jurídica del Estado. Dykinson, Madrid, 2001. (Trad. María Venegas Grau). Pág. 183.

11. Hacemos la advertencia que usaremos el calificativo "constitucional" para aludir a aquello relativo a una Constitución, y "constitucionalista" a lo tocante al Constitucionalismo.

12. NINO, ob. cit. Pág. 4.

13. TROPER, ob. cit. Pág. 184.

14. En este mismo sentido, véanse: SÁNCHEZ AGESTA, ob. cit. Pág. 46; ATIENZA, ob. cit. Pág. 265 y AGUILÓ REGLA, Josep: “Sobre las contradicciones (tensiones) del constitucionalismo y las concepciones de la constitución”. En: Carbonell y García Jaramillo, ob. cit. Pág. 249.

15. COMANDUCCI, Paolo: "Formas de (neo) constitucionalismo: Un análisis metateórico". En: Carbonell, Miguel (edic.): Neoconstitucionalismo(s). Trotta, Madrid, $4^{a}$ ed., 2009. Pág. 77.

Facultad de Derecho y Ciencias Sociales - Universidad de Valparaíso - Chile 
constitucionalismo político, ya que en este caso, la limitación al poder se expresa a través de la limitación específicamente a los órganos dotados de potestades normativas, principalmente el legislador, con el objeto de resguardar el contenido de la Constitución.

En nuestra opinión, cada uno de los sentidos reseñados involucra además distintas concepciones en torno a la idea de Constitución. En el primer caso, se alude a una norma suprema, cúspide del ordenamiento jurídico, o sea "la norma o normas positivas que regulan la producción de normas jurídicas generales"16; en el segundo, a la noción de Constitución como límite que, siendo suprema, sea "el dispositivo fundamental para el control del proceso del poder"17; y en el tercero, a la Constitución como garante, que corresponde a la formulación contenida en el art. 16 de la Declaración francesa de los Derechos del Hombre y el Ciudadano que señala que: "una sociedad en la que la garantía de los derechos no esté asegurada, ni la separación de los poderes esté determinada, no tiene Constitución".

En atención a que - a menos que hablemos de constitucionalismo en sentido mínimo- el constitucionalismo en sentido jurídico siempre supone la existencia de normas limitadoras del poder político, los autores, a partir de este carácter, construyen diversas categorías y clasificaciones. Ferrajoli, por ejemplo, habla por una parte del constitucionalismo principialista, donde los derechos fundamentales operan con una normatividad débil, vale decir, no como reglas sino sólo como valores o principios morales susceptibles de ser ponderados por el legislador y por los jueces; y por la otra, del constitucionalismo garantista, que se caracteriza porque los derechos gozan de normatividad fuerte, imponiendo deberes positivos o negativos al legislador, cuyo incumplimiento puede generar "antinomias por acción o lagunas por omisión” ${ }^{18}$. Troper agrega a los dos sentidos ya expuestos, el constitucio-

16. KELSEN, Hans: Teoría Pura del Derecho. Porrúa, México D.F., $15^{a}$ ed., 2007. Pág. 232

17. LOEWENSTEIN, Karl: Teoría de la Constitución. Ariel, Barcelona, 2a ed. 1970. (Trad. Alfredo Gallego Anabitarte). Pág. 150.

18. FERRAJOLI, ob. cit. Págs. 16-17.

Revista de Ciencias Sociales - Número 67 (2015) - Universidad de Valparáíso - ISSN 0716-7725-Valparaíso, Chile 
nalismo strictissimo sensu, que exige la necesidad del control de constitucionalidad de las leyes como medio para impedir el despotismo o para garantizar la libertad política ${ }^{19}$.

Si se entiende a las Constituciones primero, como límite al poder político, específicamente a las potestades normativas, que puede hacerse efectivo mediante garantías jurisdiccionales previstas en el mismo texto constitucional y luego, como normas que gozan de rigidez que impiden al legislador poder modificarlas a su arbitrio, la operatividad del constitucionalismo así entendido, va produciendo que los valores constitucionales, al ser intangibles para el legislador, permeen, se filtren o se irradien a todo el ordenamiento. Lo anterior, por cuanto la Constitución limita la discrecionalidad del legislador y le impone deberes a la actuación para la realización de los derechos y del programa en ella contenidos ${ }^{20}$. Este fenómeno, conocido como "constitucionalización del derecho" es asumido por Guastini como un proceso de transformación de un ordenamiento al término del cual el ordenamiento en cuestión resulta totalmente "impregnado" por las normas constitucionales. Este mismo autor, por su parte, advierte que la constitucionalización no es un concepto bipolar, y por lo mismo, no mide si un ordenamiento está o no constitucionalizado, sino que es una cuestión de grado por lo que en rigor, se podrá determinar si está más o menos constitucionalizado ${ }^{21}$.

Como se advierte, por mucho que se intente hacer esfuerzos por deslindar el constitucionalismo jurídico del político, no existe una separación absoluta entre ambos. Es cierto que el constitucionalismo jurídico se construye a partir de la observación y de las exigencias que se puedan realizar respecto de los ordenamientos jurídicos, a través de

19. TROPER, ob. cit. Pág. 184.

20. BARROSO, Luis Roberto: El neoconstitucionalismo y la constitucionalización del Derecho. El triunfo tardío del derecho constitucional en Brasil. Instituto de Investigaciones Jurídicas, serie Estudios Jurídicos $\mathrm{N}^{\circ} 127$, Universidad Nacional Autónoma de México, México D.F., 2008. Pág. 20.

21. GUASTINI, Riccardo: “La 'constitucionalización' del ordenamiento jurídico: El caso italiano”. En: Carbonell: Neoconstitucionalismo(s), ob. cit. Págs. 49 y ss.

Facultad de Derecho y Ciencias Sociales - Universidad de Valparaíso - Chile 
lo que Ferrajoli llama "las garantías internas" de los mismos ${ }^{22}$, sin embargo no es posible (a menos que se use la expresión constitucionalismo en su inútil sentido mínimo) despojar a esta noción de la idea de Constitución como límite al poder del Estado, lo cual de por sí representa un contenido político de relevancia. De allí que Ansuátegui resuma el sentido del constitucionalismo de modo preciso, como "una propuesta doctrinal en relación con la limitación del Poder a través del Derecho"23.

\section{Constitucionalismo en sentido político}

Por su parte, vamos a entender por Constitucionalismo en sentido político, los usos que se le da a este término desde la perspectiva de la Teoría Política o de la Filosofía Política, a partir de una observación del fenómeno del poder y de su articulación al interior de una sociedad. Manteniendo el esquema propuesto por Ferrajoli, el constitucionalismo político se manifiesta a través de lo que él denomina "garantías políticas externas" a los sistemas jurídicos, vinculadas en su visión a la limitación de los poderes públicos para garantizar determinados ámbitos de libertad ${ }^{24}$.

Dentro del uso político de la expresión constitucionalismo, es posible advertir a su vez, cuatro manifestaciones, o si se permite, cuatro sub-usos de esta palabra, a saber: constitucionalismo como formas históricas de organización, como construcción teórica, como movimiento y como modelo.

\subsection{Constitucionalismo político como formas históricas de organización}

Esta primera perspectiva consiste en una descripción de los sistemas políticos que han contado con una constitución. Como a su

22. FERRAJOLI, ob. cit. Pág.13.

23. ANSUÁTEGUI ROIG, Francisco Javier: "Razón y voluntad en el Estado de Derecho: Un enfoque filosófico-jurídico”. Instituto de Derechos Humanos Bartolomé de las Casas, Universidad Carlos III de Madrid, Dykinson, 2013. Pág. 225.

24. FERRAJOLI, ob. cit. Pág. 13.

Revista de Ciencias Sociales - Número 67 (2015) - Universidad de Valparáíso - ISSN 0716-7725-Valparaíso, Chile 
vez el concepto de constitución ha ido variando con el tiempo, desde la idea de ella como politeia ${ }^{25}$ o "el estado como es en la realidad" aquél que reconoce en la constitución su carácter normativo, el constitucionalismo ha ido mutando también.

Hacia 1940, McIlwain afirmaba que la época era propicia para estudiar el constitucionalismo en un examen que atienda a los estadios propios de su desarrollo ${ }^{27}$, asumiendo que su cualidad esencial es la limitación jurídica del gobierno, como antítesis del gobierno arbitrario o despótico, o sea, la sustitución del gobierno del capricho por un gobierno del derecho ${ }^{28}$. Dicho de esta manera, cada forma de organización que cuente con una constitución que cumpla con dicho fin restrictivo, será una forma de constitucionalismo. Lo anterior lleva al autor a distinguir un primer constitucionalismo histórico, "el antiguo", donde en mayor o menor medida era posible hallar límites al ejercicio del poder, tanto por la exigencia de un gobierno justo y moderado en Grecia, como por el sometimiento al Derecho Natural en Roma, según las ideas de Cicerón. También forma parte del constitucionalismo antiguo, el de la Edad Media, caracterizado por la existencia de ciertos privilegios y libertades garantizados por el rey y que, por lo mismo, estaba obligado a respetar ${ }^{29}$. Sin embargo, "el constitucionalismo moderno" se identifica con el sometimiento del gobernante a leyes emanadas del Parlamento, en un proceso que luego de décadas, se consolida con la Gloriosa Revolución de 1688-1689 y el inicio de la monarquía constitucional en Inglaterra ${ }^{30}$.

25. La idea de politeia es meramente descriptiva, tanto que hay una gran semejanza con la descripción de un organismo humano. Por lo mismo, llevó a un autor llamar la "acepción médica" de constitución. DIPPEL, Horst: Constitucionalismo moderno. Marcial Pons, Madrid, 2009. (Trad. Clara Álvarez Alonso y María Salvador Martínez). Pág. 13.

26. MCILWAIN, ob. cit. Pág. 45.

27. Ídem. Pág. 15.

28. Ídem. Pág. 37.

29. Ídem. Págs. 108-111.

30. Ídem. Págs. 155-179.

Facultad de Derecho y Ciencias Sociales - Universidad de Valparaíso - Chile 
El término "Constitucionalismo Moderno" será recogido más tarde por Dippel ${ }^{31}$ para estudiar aquel fenómeno que tiene sus antecedentes en la mencionada revolución inglesa, pero que estrictamente se inicia con la promulgación de la Declaración de Derechos de Virginia del 12 de junio de $1776^{32}$, seguida de las Constituciones de Pensilvania de 1776, de Estados Unidos de 1787, la Jacobina de 1793, la de Cádiz de 1812, la del Reino de Westfalia de 1807 y el proceso de Constitucionalización en Alemania desde 1831 a 1949, entre otros hitos relevantes. Este constitucionalismo se caracteriza por cinco primeros principios, como son los de soberanía popular, una Constitución fundada en principios universales, una declaración de derechos, un gobierno limitado y la Constitución como ley suprema. A ellos, se agregan otros cinco orientados a conseguir que las tareas constitucionales se adecuen a las metas perseguidas por el constitucionalismo moderno, a saber: un gobierno representativo, la separación de poderes, la rendición de cuentas y responsabilidad gubernamental, la independencia judicial, y un proceso ordenado para enmendar, corregir o completar la Constitución con el concurso del pueblo o de sus representantes ${ }^{33}$.

\subsection{Constitucionalismo político como construcción intelectual}

Dentro de esta categoría se incluye el concepto que proporciona Fioravanti, quien en un primer trabajo señaló que el constitucionalismo "es concebido como el conjunto de doctrinas que aproximadamente a partir de la mitad del siglo XVII se han dedicado a recuperar en el horizonte de la constitución de los modernos el aspecto del límite y de la garantía" ${ }^{34}$. Más tarde, desarrolla en mayor detalle esta idea, reformulando su definición

\footnotetext{
31. DIPPEL, ob. cit. Pág. 185.

32. Ibídem.

33. Ídem. Págs. 44-45

34. FIORAVANTI, Maurizio: Constitución. De la antigüedad a nuestros días. Trotta, Madrid, 2001. (Trad. Manuel Martínez Neira). Pág. 85.
}

Revista de Ciencias Sociales - Número 67 (2015) - Universidad de Valparáíso - ISSN 0716-7725-Valparaíso, Chile 
al indicar que "el constitucionalismo es, desde sus orígenes, una corriente de pensamiento encaminada a la consecución de finalidades políticas concretas consistentes, fundamentalmente, en la limitación de los poderes públicos y en la consolidación de esferas de autonomía garantizadas mediante normas" 35 . De esta manera, el autor destaca que el constitucionalismo encerraría tres aspectos: (1) es un conjunto de doctrinas o una corriente de pensamiento; (2) es evolutivo, encontrando sus antecedentes en la filosofía política griega, pero concretándose solo a partir de las revoluciones liberales que comienzan en el siglo XVII en Europa; y (3) tiene una finalidad, como es la de limitar los poderes públicos de manera de garantizar "esferas de autonomía" mediante normas, entendiendo por "esferas de autonomía" tanto la de los estamentos y las ciudades frente al señor territorial a comienzos de la edad moderna, como la de los derechos fundamentales presentes en las constituciones actuales ${ }^{36}$.

Sin poder adentrarnos con mayor detalle en el pensamiento de Fioravanti, su estructura conceptual nos será útil para distinguir que el constitucionalismo político, entendido como construcción intelectual se acerca a la fórmula "constitucionalismo es un $X$ que busca $Y$ en o a partir de Z”. En esta ecuación, la variable X representa el elemento sustantivo, esto es, la categoría conceptual a la cual pertenece el constitucionalismo como objeto de estudio; la variable Y simboliza el elemento finalista, que son los objetivos que pretende el constitucionalismo; y la variable $\mathrm{Z}$ se refiere al elemento histórico que permite situar al constitucionalismo, como tal o en sus orígenes, en una época determinada.

Respecto del elemento sustantivo, desde esta perspectiva, el constitucionalismo es un conjunto de elaboraciones teóricas, que pueden estar más o menos recogidas por la comunidad científica, pero que no necesariamente se manifiestan en cambios en los textos constitucionales mismos, ni se transforman en reivindicaciones sociales de importancia.

35. FIORAVANTI, Maurizio: Constitucionalismo. Experiencias históricas y tendencias actuales. Trotta, Madrid, 2014. (Trad. Adela Mora Cañada y Manuel Martínez Neira). Pág. 17.

36. Ídem. Págs. 9-10.

Facultad de Derecho y Ciencias Sociales - Universidad de Valparaíso - Chile 
Además de lo dicho por Fioravanti, otros autores usan expresiones como "doctrina" 37 "ideología" 38 o "propuesta doctrinal" 39 para referirse al constitucionalismo.

En relación con el elemento finalista, se advierten distintos objetivos del constitucionalismo, siendo tres los más habituales o recurrentes. El primero de ellos alude a la limitación del poder político ${ }^{40}$, fundamentalmente como un conjunto de reglas escritas que frenan los excesos de los gobernantes. Para obtener esta finalidad, el constitucionalismo se servirá, tal como lo abordaremos en las próximas páginas, de diferentes herramientas como por ejemplo, la separación de los poderes.

Un segundo objetivo es aún anterior a la restricción del poder, y es el de generar la organización política de la comunidad. El fundamento está en las teorías contractualistas inauguradas por Hobbes en el Capítulo XVII del Leviatán ${ }^{41}$. Y si bien el constitucionalismo así entendido suele ser entendido bajo la lógica de entender la constitución como pacto ${ }^{42}$, de lo cual deriva el principio que el poder constituyente

37. ZAGREBELSKY, Gustavo: “Constitucionalismo". En: Revista Derechos y Libertades, Instituto de Derechos Humanos Bartolomé de las Casas, Universidad Carlos III, Madrid, N²9, época II, junio 2013. Pág. 20.

38. TAJADURA TEJADA, Javier: “¿El ocaso de Westfalia? Reflexiones en torno a la crisis del constitucionalismo en el contexto de la mundialización”. En: Revista de Estudios Políticos, Centro de Estudios Políticos y Constitucionales, Madrid, $\mathrm{N}^{\circ}$ 123, enero-marzo 2004. Pág. 318.

39. ANSUÁTEGUI, ob. cit. Pág. 225.

40. Véanse ibídem y PERALTA, Ramón: La Constitución como sistema de libertad. 2008. Pág. 31.

Fundamentos político-jurídicos de la república constitucional. Actas, Madrid,

41. HOBBES, Thomas: Leviatán o la materia, forma y poder de una república eclesiástica y civil. Fondo de Cultura Económica, México D.F., 2 ed., 1980.

(Trad. Manuel Sánchez Sarto). Págs. 137 y ss.

42. "En dos siglos de constitucionalismo son sorprendentemente abundantes las concepciones que se han sucedido sobre el concepto y la significación de la Constitución en la teoría y la práctica (...) El elemento más esencial y característico de la idea es el pacto”. Véase MUNOZZ MACHADO, Santiago: Constitución. Iustel, Madrid, $1^{\mathrm{a}}$ ed., 2004. Pág. 19.

Revista de Ciencias Sociales - Número 67 (2015) - Universidad de Valparáíso - ISSN 0716-7725-Valparáiso, Chile 
originario reside en el pueblo ${ }^{43}$, también puede ser interpretado bajo el decisionismo de Carl Schmitt, para quien el poder constituyente puede o no pertenecer al pueblo, puesto que lo entiende como aquella "voluntad política cuya fuerza o autoridad es capaz de adoptar la concreta decisión de conjunto sobre modo y forma de la propia existencia política" 4 . En este segundo objetivo, el constitucionalismo no tiene por función "limitar al Estado", sino mucho más que eso, busca "crear al Estado", organizando sus poderes ${ }^{45}$, determinando la "esencia estructural y funcional de la vida política" en palabras de Pérez Serrano ${ }^{46}$.

Finalmente, el tercer objetivo ${ }^{47}$ se refiere a la garantía de los derechos fundamentales. Estos derechos, y la proclama de la libertad constituyen el eje del "programa histórico" del constitucionalismo, según

43. Sobre la calidad del pueblo como titular del Poder Constituyente, véase BÖCKENFÖRDE, Ernst: "El poder constituyente del pueblo. Un concepto límite del derecho constitucional”. En: Böckenförde, Ernst: Estudios sobre el Estado de Derecho y la Democracia. Trotta, Valencia, 2000. (Trad. Rafael de Agapito Serrano). Págs. 159 y ss. En Chile, Bassa Mercado, Jaime: Elementos para una teoría constitucional democrática. Librotecnia, Santiago de Chile, $1^{\text {a }}$ ed., 2014. Págs. 93 y ss.

44. SCHMITT, Carl: Teoría de la Constitución. Alianza, Madrid, $1^{\mathrm{a}}$. ed., 1996. (Trad. Francisco Ayala). Págs. 93-94.

45. SÁNCHEZ AGESTA, Luis: Curso de derecho constitucional comparado. Universidad de Madrid, Facultad de Derecho, sección de publicaciones, Madrid, 7a. ed., 1988. Pág. 46.

46. PÉREZ SERRANO, Nicolás: Tratado de Derecho Político. Civitas, Madrid, 2a . ed., 1997. Pág. 438.

47. Se ha excluido conscientemente otros principios que algunos autores han identificado como propios del constitucionalismo, por entender que más que objetivos del mismo, representan técnicas o herramientas para hacer efectivos tales objetivos, como sucede con la separación de los poderes o la existencia de un sistema democrático. Al respecto véanse TAJADURA, ob. cit. Pág. 316 y ALTERIO, Ana Micaela: "La 'esfera de lo indecible' en el constitucionalismo de Luigi Ferrajoli: un análisis crítico". En: Universitas. Revista de Filosofía, Derecho y Política, Instituto de Derechos Humanos "Bartolomé de las Casas", Universidad Carlos III de Madrid, $\mathrm{N}^{\circ} 13$, enero 2011. Págs. 3 y ss.

48. BLANCO VALDÉS, Roberto L.: La Constitución de la libertad. Apuntes para

Facultad de Derecho y Ciencias Sociales - Universidad de Valparaíso - Chile 
nos dice Blanco ${ }^{48}$. La soberanía que, bajo la tesis de Bodin sólo reconocía como límite el derecho natural y los acuerdos suscritos por el monarca ${ }^{49}$, reconoce frenos en la doctrina constitucionalista correspondientes al respeto por estos derechos, de allí que la única finalidad del Estado bajo el constitucionalismo, en palabras de Díez-Picazo, sea "proteger esos derechos" $"$. Con el tiempo, los derechos fundamentales no sólo se relacionarán con el Estado limitando su poder (exigencias negativas), sino que también imponiéndole deberes asociados a la garantía de la dignidad humana (exigencias positivas). Esto último explica por qué entendemos que este objetivo es diferente al primero mencionado, esto es, el de limitar el poder, puesto que es más amplio y no se satisface con la sola inactividad por parte de los órganos estatales.

Para terminar, en lo que respecta al tercer elemento del constitucionalismo, el histórico, este dependerá en buena medida de las opciones que se hayan adoptado en relación con el elemento sustantivo, pero fundamentalmente, con el elemento finalista. Así, si entendemos que el objetivo del constitucionalismo será el de crear y organizar el poder, su origen arrancará en el contractualismo principalmente de Hobbes, lo que nos permite, según Schiera permite "sacar al constitucionalismo de la perspectiva algo reduccionista de mera oposición al absolutismo del antiguo régimen para darle, en cambio, un valor más amplio y estructural como elemento esencial de la dinámica del Estado moderno" ${ }^{\prime 1}$. En este mismo sentido, se ha sostenido que la construcción de un Estado dotado del monopolio de la fuerza y de la jurisdicción se inicia a partir de la Paz de Westfalia (1648), al término

una historia del constitucionalismo europeo. Alianza, Madrid, 2010. Pág. 139.

49. BODIN, Jean: Los seis libros de la República. Tecnos, Madrid, $3^{\mathrm{a}}$ ed., 1997. (Trad. Pedro Bravo Gala). Págs. 47 y ss.

50. DÍEZ-PICAZO GIMÉNEZ, Luis María: Sistema de Derechos Fundamentales. Civitas, Madrid, $4^{a}$ ed., 2013. Pág. 27.

51. SCHIERA, Pierangelo: El constitucionalismo como discurso. Dykinson, Madrid, 2012. (Trad. Adela Mora Cañada y Manuel Martínez Neira). Pág. 24.

52. TAJADURA, ob. cit. Pág. 322.

Revista de Ciencias Sociales - Número 67 (2015) - Universidad de Valparáíso - ISSN 0716-7725-Valparáiso, Chile 
de la Guerra de los Treinta Años, siendo éste el momento en el que se inicia la implementación de las ideas constitucionalistas de Hobbes referidas a la construcción del Estado ${ }^{52}$. Ahora bien, si se piensa que lo que se busca el constitucionalismo es limitar el poder, Loewenstein sostiene que es posible hablar de constitucionalismo en el antiguo régimen teocrático de los hebreos, ya que allí era posible encontrar límites al poder político, representados por "la ley del Señor" obstante ello, el constitucionalismo moderno, en los términos ya estudiados de McIlwain y Dippel, caracterizado por la existencia de normas jurídicas emanadas del pueblo o de sus representantes, solo encontrará sus inicios en los movimientos liberales burgueses del Siglo XVII y XVIII en Inglaterra, Estados Unidos y Francia ${ }^{54}$.

\subsection{Constitucionalismo político como movimiento}

Esta concepción es complementaria a aquella forma de concebir al constitucionalismo como construcción intelectual, ya que entiende que el constitucionalismo no se reduce a teorías filosóficas o científicas sino que tiene manifestaciones sociales, expresadas en reivindicaciones de derechos frente a quienes ejercen el poder. El matiz puede ser sutil, pero relevante. Sostengo que es posible separar los trabajos académicos que se discuten en los distintos círculos de debate, de las fuerzas sociales que persiguen cambios políticos en el plano de la reforma o de la revolución.

André Hauriou sostiene que en una estructura social existe un antagonismo permanente entre poder y libertad. Con el objeto que el ejercicio de esta última no devenga finalmente en disgregación, actúa el poder oponiéndose a esa amenaza. Esto alimenta un rechazo o

53. LOEWENSTEIN, ob. cit. Pág. 154.

54. Al respecto, véase SEGOVIA, Juan: "Ley natural, contrato social y poder constituyente en el pensamiento anglosajón y francés". En: Ayuso Torres, Miguel (dir.): El problema del poder constituyente. Constitución, soberanía y representación en la época de las transiciones. Marcial Pons, Madrid, 2012. Pág. 37.

Facultad de Derecho y Ciencias Sociales - Universidad de Valparaíso - Chile 
"impugnación" a la autoridad, el cual puede ser reprimido, como sucedería con las sociedades orientales (Medio Oriente, India, China), o bien aceptado y utilizado para el funcionamiento mismo de los mecanismos políticos ${ }^{55}$. Esto último constituiría, en la visión de Hauriou, un invento occidental el cual se desarrollaría a través del diálogo y una organización racional. Esta dialéctica entre poder y libertad, o entre autoridad e impugnación se formaliza o expresa a través de los movimientos constitucionales, los cuales se caracterizan por que "los factores conscientes o voluntarios predominan sobre los inconscientes o sobre los accidentes" 56 . Un "movimiento constitucional" corresponde a "un impulso de origen nacional por el que un pueblo se esfuerza en limitar lo arbitrario del poder que le dirige, reivindicando la 'libertad política', es decir, el derecho de los ciudadanos a participar del gobierno e incluso a proporcionar a los gobernantes, al mismo tiempo que las libertades individuales'”' ${ }^{\prime}$. Agrega que estos movimientos son locales, que se producen en épocas determinadas, por lo que describirlos es hacer historia constitucional comparada, y además deberán ser espontáneos para que sean auténticos y sinceros ${ }^{58}$. Por último, contienen un componente jurídico, representado por la fe jurídica, o sea, aquella confianza de que las "peripecias de la lucha, las iniciativas de los ciudadanos o las resistencias de los gobernantes, de lo que se trata es de la sumisión del Estado al Derecho" 59 .

Es en este contexto en el que el constitucionalismo puede ser entendido como un movimiento constitucional, un impulso político que trata de incidir en mayores espacios de participación política y en el resguardo de los derechos y libertades que, aun cuando tiene

\footnotetext{
55. HAURIOU, André: Derecho constitucional e instituciones políticas. Ariel, Barcelona, $2^{a}$ ed., 1980. (Trad. José Antonio González Casanova). Págs. 50 y ss.

56. Ídem. Pág. 198.

57. Ibídem.

58. Ídem. Pág. 199.

59. Ídem. Pág. 209.
}

Revista de Ciencias Sociales - Número 67 (2015) - Universidad de Valparáíso - ISSN 0716-7725-Valparaíso, Chile 
expresiones locales, su sistematización histórica puede llevar a concluir ciertas líneas comunes, y una determinada evolución. Jiménez Asensio explica acertadamente esta idea cuando señala que el fenómeno del constitucionalismo no es otra cosa sino que "la lucha por la limitación del poder y la conquista de la libertad frente a la arbitrariedad y el despotismo" ${ }^{\prime \prime}$, demostrando el carácter sociológico del constitucionalismo y no meramente teórico.

Entendido de esta manera, el constitucionalismo político tiene además un carácter conflictual en relación con quien detente el poder, lo que ha llevado a que su estudio y divulgación se encuentre prohibido en regímenes dictatoriales, como en China ${ }^{61}$. Es que el constitucionalismo se transforma en una incomodidad para la autoridad, ya que lleva ínsito la idea de límite y resistencia al poder.

\subsection{Constitucionalismo político como modelo(s) ideal(es)}

El Diccionario de la Real Academia Española de la Lengua define un modelo como "arquetipo o punto de referencia para imitarlo o reproducirlo" 62 . En este caso, la expresión constitucionalismo es usada como patrón o medida que sirve para medir o determinar la legitimidad de un sistema jurídico o político, o su cercanía o lejanía de algún tipo

60. JIMÉNEZ ASENSIO, Rafael: El Constitucionalismo: Proceso de formación y fundamentos del Derecho constitucional. Marcial Pons, Madrid, $3^{\text {a }}$ ed., 2005.

Pág. 24.

61. Anne Peters menciona el caso de un profesor de Derecho de la Universidad de China Oriental que fue sancionado, retirándole su acreditación docente por haber enseñado e investigado en sus aulas acerca del constitucionalismo, palabra cuyo uso está prohibido por el Partido Comunista y el Estado chino, por atentar en contra de la "dictadura democrática del pueblo". PETERS, Anne: "El constitucionalismo como conquista global”. En: González-Aurioles, Jorge y Gutiérrez Gutiérrez, Ignacio (eds.): Constitución: norma y realidad, Teoría constitucional para Antonio López Pina. Marcial Pons, Madrid, 2014. Pág. 247.

62. Real Academia Española, Diccionario de la lengua española. 22a . edición. Revisado el día 6 de agosto de 2015. Enlace: http://lema.rae.es/drae/ ?val $=$ modelo

Facultad de Derecho y Ciencias Sociales - Universidad de Valparaíso - Chile 
de constitucionalismo en particular. Una característica importante de este uso es la atemporalidad y abstracción del constitucionalismo, toda vez que no está asociado necesariamente a una época determinada de la Historia, adquiriendo autonomía como baremo. El modelo constitucionalista, en genérico, o aquél particular del constitucionalismo social, liberal, democrático, etc., será el resultado de elaboraciones doctrinarias (constitucionalismo como construcción teórica) o de exigencias sociales (constitucionalismo como movimiento), pero que se mantendrá de modo autónomo, disociándolo de su origen ${ }^{63}$.

A manera ejemplar, Pisarello explica que la noción de constitucionalismo supone un sistema axiológico de la modernidad ligado a la necesidad de establecer límites y vínculos al poder y a garantizar la autonomía de las personas ${ }^{64}$, lo que permitiría detectar casos de constituciones que no se ajustan a dichos parámetros ("constituciones no constitucionalistas" o "constituciones sin constitucionalismo") y prácticas que ajustándose a dichos principios no tienen manifestación en textos fundamentales concretos ("constitucionalismo sin constitución") ${ }^{65}$.

Como sostiene La Torre, las dos versiones del constitucionalismo, la de los antiguos y la de los modernos, no sólo puede ser entendida desde un punto de vista histórico o diacrónico, sino también desde una perspectiva ideal-típica, que permitiría constatar en la actualidad que ambas versiones pueden coexistir, manifestándose en experiencias concretas de constitución ${ }^{66}$. Otro autor, reconocerá también como dos

63. En un sentido similar, pero referido al Estado Constitucional, Peter Häberle ha indicado que ha funcionado como "arquetipo" que tiene como elementos fundamentales la dignidad humana y la soberanía popular. Véase HÄBERLE, Peter: Teoría de la Constitución como ciencia de la cultura. Tecnos, Madrid, $1^{a}$ ed., 2000. (Trad. Emilio Mikunda). Pág. 33.

64. PISARELLO PRADOS, Gerardo: “¿Constitucionalismo sin Constitución o Constitución sin constitucionalismo?” En: Revista de derecho constitucional europeo, Instituto Andaluz de Administración Pública y Universidad de Granada, Granada, $N^{\circ}$ 5, año 2006. Pág. 247.

65. Ídem. Pág. 248.

66. LA TORRE, Massimo: "Constitucionalismo de los antiguos y de los modernos. Constitución y 'Estado de excepción””. En: Revista Derechos y Libertades, Instituto de Derechos Humanos Bartolomé de las Casas, Universidad Carlos III, Madrid, N²4, época II, enero 2011. Pág. 46.

Revista de Ciencias Sociales - Número 67 (2015) - Universidad de Valparáíso - ISSN 0716-7725-Valparáiso, Chile 
formas de constitucionalismo, el aspiracional y el preservador, siendo el primero aquél que busca el progreso, y el segundo el que persigue la limitación del poder, siendo ambos, nuevamente "tipos ideales", ya que se trata de una distinción de "carácter más analítico que descriptivo"67.

\section{Constitucionalismo político y derechos fundamentales}

Como se ha visto uno de los objetivos centrales del constitucionalismo político es entregar una fórmula constitucional que permita proteger los derechos fundamentales, en relación con las amenazas o riesgos provenientes del ejercicio del poder, a través de herramientas contempladas en el sistema constitucional. De este modo, se sostendrá en este trabajo que existen tres criterios o variables que permitirán diferenciar entre sí a las diversas formas o tradiciones del constitucionalismo, en lo referente a dicha relación entre poder y derechos fundamentales.

La primera variable será la determinación del tipo de poder que es asumido como una amenaza a los derechos fundamentales. Esto por cuanto en algunos casos, se entiende que los riesgos provienen exclusivamente del Estado y de sus órganos, pero en otras formas de constitucionalismo, aquellos pueden emanar de otras vías de poder o dominación.

El segundo criterio se relaciona con el tipo de derechos fundamentales que se sienten amenazados por aquel poder que se asume como riesgo. La historia de los derechos fundamentales reconoce diferentes generaciones de los mismos, las cuales se han construido principalmente en virtud de esta relación que se produce entre derechos y poder. Cada tradición de constitucionalismo se ocupará de enfatizar alguna categoría de derechos que está especialmente amenazada por quien detenta jurídica o fácticamente el poder dentro de una comunidad.

67. GARCÍA VILLEGAS, Mauricio: "Constitucionalismo aspiracional". En: Araucaria. Revista Iberoamericana de Filosofía, Política y Humanidades, Universidad de Sevilla, Sevilla, N²9 (monográfico: "Colombia: Desafíos y posibilidades de una nación en construcción”), primer semestre de 2013. Pág. 80.

Facultad de Derecho y Ciencias Sociales - Universidad de Valparaíso - Chile 
La tercera de las variables serán las herramientas que propongan cada forma o tradición de constitucionalismo para obtener la protección de los derechos fundamentales amagados por el ejercicio del poder. En este caso, se entra al ámbito de las "garantías de derechos”, entendiendo por ellas no sólo el "conjunto de medios que el ordenamiento prevé para la protección, tutela o salvaguarda de los derechos fundamentales" como se define comúnmente ${ }^{68}$ y propio de un análisis de lege data, sino que más bien en las propuestas de diseño de la relación poder-derechos y por lo mismo, que se desarrolla a nivel de lege ferenda, sin perjuicio que dichas ideas se plasmen o no en la constitución escrita.

Sobre este punto, se pueden reconocer al menos cuatro tradiciones de constitucionalismo, a saber: el constitucionalismo liberal, el constitucionalismo social y democrático, el neoconstitucionalismo y el constitucionalismo popular. Las dos primeras tradiciones tienen en común que se tratan de modelos que han sido recogidos positivamente "en las constituciones", mientras que las dos posteriores se trata más bien de aproximaciones "acerca de las constituciones" sin que necesariamente existan concreciones normativas específicas. Recientemente se ha reconocido la existencia de un nuevo movimiento denominado Nuevo Constitucionalismo Latinoamericano, presente en las cartas de Venezuela (1999), Ecuador (2006) y Bolivia (2009), para lo cual se hará necesario un estudio más profundo acerca de cómo operan estas variables en relación con él.

\section{Conclusión}

Uno de los inconvenientes teóricos al momento de estudiar el constitucionalismo son los diferentes usos que se proporciona a dicha expresión.

Lo que ha pretendido este trabajo es brindar una suerte de panorama general en torno a los diferentes contextos en los que se emplea este término. Probablemente la única zona de contacto entre estas diferentes acepciones obedece a la idea de constitución y a los diferentes roles que ella ocupa: como norma fundamental y fundante

68. DÍEZ-PICAZO, ob. cit. Pág. 69.

Revista de Ciencias Sociales - Número 67 (2015) - Universidad de Valparáíso - ISSN 0716-7725-Valparáiso, Chile 
de un ordenamiento jurídico, en cuyo caso se hablará de constitucionalismo jurídico, en un terreno muy cercano al neoconstitucionalismo, o bien, como estructura política o como mecanismo de ordenación y de limitación del poder, de lo cual derivará el constitucionalismo político.

Contextualizar el discurso cuando un hablante se aproxime al fenómeno del constitucionalismo será determinante para poder esclarecer el sentido del mismo, que es algo que no siempre se constata en los trabajos de los autores.

\section{BIBLIOGRAFÍA}

AGUILÓ REGLA, Josep: "Sobre las contradicciones (tensiones) del constitucionalismo y las concepciones de la constitución”. En: Carbonell, Miguel y García Jaramillo, Leonardo (edic.): El canon neoconstitucional. Trotta, Madrid, 2010.

ALTERIO, Ana Micaela: "La 'esfera de lo indecible' en el constitucionalismo de Luigi Ferrajoli: un análisis crítico". En: Universitas. Revista de Filosofía, Derecho y Política, Instituto de Derechos Humanos "Bartolomé de las Casas", Universidad Carlos III de Madrid, $\mathrm{N}^{\circ} 13$, enero 2011. Pág. 3 y ss.

ANSUÁTEGUI ROIG, Francisco Javier: Razón y voluntad en el Estado de Derecho: Un enfoque filosófico-jurídico. Instituto de Derechos Humanos Bartolomé de las Casas, Universidad Carlos III de Madrid, Dykinson, 2013.

ATIENZA, Manuel: "Constitucionalismo, Globalización y Derecho". En: Carbonell, Miguel y García Jaramillo, Leonardo (edic.): El canon neoconstitucional. Trotta, Madrid, 2010.

BARROSO, Luis Roberto: El neoconstitucionalismo y la constitucionalización del Derecho. El triunfo tardío del derecho constitucional en

Brasil. Instituto de Investigaciones Jurídicas, serie Estudios Jurídicos N 127, Universidad Nacional Autónoma de México, México D.F., 2008. BASSA MERCADO, Jaime: Elementos para una teoría constitucional democrática. Librotecnia, Santiago de Chile, $1^{\mathrm{a}}$ ed., 2014.

BLANCO VALDÉS, Roberto L.: La Constitución de la libertad. Apuntes para una historia del constitucionalismo europeo. Alianza, Madrid, 2010.

Facultad de Derecho y Ciencias Sociales - Universidad de Valparaíso - Chile 
BÖCKENFÖRDE, Ernst: "El poder constituyente del pueblo. Un concepto límite del derecho constitucional". En: Böckenförde,

Ernst: Estudios sobre el Estado de Derecho y la Democracia. Trotta, Valencia, 2000. (Trad. Rafael de Agapito Serrano). Págs. 159 y ss.

BODIN, Jean: Los seis libros de la República. Tecnos, Madrid, $3^{\mathrm{a}}$ ed., 1997. (Trad. Pedro Bravo Gala).

BREWER-CARÍAS, Allan: El constitucionalismo Latinoamericano y la Constitución para el Siglo XXI. Discurso de Orden con motivo de la instalación de las V Jornadas Venezolanas de Derecho Tributario, Asociación Venezolana de Derecho Tributario, Caracas, 25 de Octubre de 2000. Disponible en: http://www.allanbrewercarias.com/Content/ 449725d9-flcb-474b-8ab2-41 efb849fea2/Content/I.1.801.pdf (revisado el día 26 de julio de 2015).

CARPIZO, Jorge: "Tendencias actuales del constitucionalismo latinoamericano". En: Revista Derecho del Estado, Universidad Externado de Colombia, Bogotá, $\mathrm{N}^{\circ} 23$, diciembre de 2009. Pág. 7 y ss. COMANDUCCI, Paolo: “Constitucionalismo': Problemas de definición y tipología”. En: Ferrajoli, Luigi et al.: Un debate sobre el constitucionalismo. Monográfico Revista Doxa, $N^{\circ} 34$, Marcial Pons, Madrid, 2012.

COMANDUCCI, Paolo: "Formas de (neo) constitucionalismo: Un análisis metateórico". En: Carbonell, Miguel (edic.): Neoconstitucionalismo(s). Trotta, Madrid, $4^{a}$ ed., 2009.

CONSTANT DE REBEQUE, Henri-Benjamin: Mélanges de littérature et de politique. Pichon et Didier, Libraires-Éditeurs, París, 1829.

DÍEZ-PICAZO GIMÉNEZ, Luis María: Sistema de Derechos Fundamentales. Civitas, Madrid, $4^{a}$ ed., 2013.

DIPPEL, Horst: Constitucionalismo moderno. Marcial Pons, Madrid, 2009. (Trad. Clara Álvarez Alonso y María Salvador Martínez).

FERRAJOLI, Luigi: "Constitucionalismo principialista y constitucionalismo garantista”. En: Ferrajoli, Luigi et al:: Un debate sobre el constitucionalismo. Monográfico Revista Doxa, $\mathrm{N}^{\circ} 34$, Marcial Pons, Madrid, 2012. FIORAVANTI, Maurizio: Constitución. De la antigüedad a nuestros días. Trotta, Madrid, 2001. (Trad. Manuel Martínez Neira). FERRAJOLI, Luigi: Constitucionalismo. Experiencias históricas y tendencias actuales. Trotta, Madrid, 2014. (Trad. Adela Mora Cañada y Manuel Martínez Neira).

Revista de Ciencias Sociales - Número 67 (2015) - Universidad de Valparaíso - ISSN 0716-7725-Valparaíso, Chile 
GARCÍA VILLEGAS, Mauricio: "Constitucionalismo aspiracional". En: Araucaria. Revista Iberoamericana de Filosofía, Política y Humanidades, Universidad de Sevilla, Sevilla, $N^{\circ} 29$ (monográfico: "Colombia: Desafíos y posibilidades de una nación en construcción”), primer semestre de 2013. Pág. 77 y ss.

GONZÁLEZ-AURIOLES, Jorge y GUTIÉRREZ GUTIÉRREZ, Ignacio (eds.): Constitución: norma y realidad. Teoría constitucional para Antonio López Pina. Marcial Pons, Madrid, 2014.

GUASTINI, Riccardo: “La 'constitucionalización' del ordenamiento jurídico: El caso italiano”. En: Carbonell, Miguel (edic.):

Neoconstitucionalismo(s). Trotta, Madrid, 4a ed., 2009.

HÄBERLE, Peter: Teoría de la Constitución como ciencia de la cultura. Tecnos, Madrid, $1^{\text {a }}$ ed., 2000. (Trad. Emilio Mikunda).

HAURIOU, André: Derecho constitucional e instituciones políticas. Ariel, Barcelona, $2^{a}$ ed., 1980. (Trad. José Antonio González Casanova).

HOBBES, Thomas: Leviatán o la materia, forma y poder de una república eclesiástica y civil. Fondo de Cultura Económica, México D.F., $2^{\circ}$ ed., 1980. (Trad. Manuel Sánchez Sarto).

JIMÉNEZ ASENSIO, Rafael: El Constitucionalismo: Proceso de formación y fundamentos del Derecho constitucional. Marcial Pons, Madrid, $3^{a}$ ed., 2005.

KELSEN, Hans: Teoría Pura del Derecho. Porrúa, México D.F., 15ª ed., 2007. (Trad. Francisco Ayala).

LA TORRE, Massimo: "Constitucionalismo de los antiguos y de los modernos. Constitución y 'Estado de excepción”. En: Revista

Derechos y Libertades, Instituto de Derechos Humanos Bartolomé de las Casas, Universidad Carlos III, Madrid, N²4, época II, enero 2011. Págs. 45 y ss.

LOEWENSTEIN, Karl: Teoría de la Constitución. Ariel, Barcelona, $2^{\text {a }}$ ed., 1970. (Trad. Alfredo Gallego Anabitarte).

MCILWAIN, Charles Howard: Constitucionalismo antiguo y moderno. Centro de estudios constitucionales, Madrid, 1991. (Trad. Juan

J. Solozábal Echavarría).

MUÑOZ MACHADO, Santiago: Constitución. Iustel, Madrid, $1^{\mathrm{a}}$ ed., 2004.

Facultad de Derecho y Ciencias Sociales - Universidad de Valparaíso - Chile 
NINO, Carlos Santiago: Fundamentos de derecho constitucional. Análisis filosófico, jurídico y politológico de la práctica constitucional. Astrea, Buenos Aires, $2^{\mathrm{a}}$ reimpr., 2002.

PERALTA, Ramón: La Constitución como sistema de libertad. Fundamentos político-jurídicos de la república constitucional. Actas, Madrid, 2008.

PÉREZ SERRANO, Nicolás: Tratado de Derecho Político. Civitas, Madrid, $2^{a}$. ed., 1997.

PETERS, Anne: "El constitucionalismo como conquista global". En: González-Aurioles, Jorge y Gutiérrez Gutiérrez, Ignacio (eds.):

Constitución: norma y realidad, Teoría constitucional para Antonio López Pina. Marcial Pons, Madrid, 2014.

PISARELLO PRADOS, Gerardo: “¿Constitucionalismo sin Constitución o Constitución sin constitucionalismo?". En: Revista de derecho constitucional europeo, Instituto Andaluz de Administración Pública y Universidad de Granada, Granada, N 5, año 2006. Págs. 245 y ss.

SÁNCHEZ AGESTA, Luis: Curso de derecho constitucional comparado. Universidad de Madrid, Facultad de Derecho, sección de publicaciones, Madrid, 7a. ed., 1988.

SCHIERA, Pierangelo: El constitucionalismo como discurso. Dykinson, Madrid, 2012. (Trad. Adela Mora Cañada y Manuel Martínez Neira).

SCHMITT, Carl: Teoría de la Constitución. Alianza, Madrid, 1ª. ed., 1996. (Trad. Francisco Ayala).

SEGOVIA, Juan: "Ley natural, contrato social y poder constituyente en el pensamiento anglosajón y francés”. En: Ayuso Torres, Miguel (dir.): El problema del poder constituyente. Constitución, soberanía y representación en la época de las transiciones. Marcial Pons, Madrid, 2012.

TAJADURA TEJADA, Javier: “¿El ocaso de Westfalia? Reflexiones en torno a la crisis del constitucionalismo en el contexto de la mundialización”. En: Revista de Estudios Políticos, Centro de Estudios Políticos y Constitucionales, Madrid, N 123, enero-marzo 2004. Pág. 315 y ss.

TROPER, Michel: Por una teoría jurídica del Estado. Dykinson, Madrid, 2001. (Trad. María Venegas Grau). 
VERGOTTINI, Giuseppe De: Derecho constitucional comparado. Universidad Nacional Autónoma de México, Segretariato Europeo per le Pubblicazioni Scientifiche, México D.F., $1^{\text {a }}$ ed., 2004. (Trad. Claudia Herrera).

WEILER, J.H.H. y WIND, Marlene (edic.): European constitutionalism beyond the state. Cambridge University Press, Cambridge, 2003.

ZAGREBELSKY, Gustavo: “Constitucionalismo”. En: Revista Derechos y Libertades, Instituto de Derechos Humanos Bartolomé de las Casas, Universidad Carlos III, Madrid, N²9, época II, junio 2013. Págs. 19 y ss.

Facultad de Derecho y Ciencias Sociales - Universidad de Valparaíso - Chile 